DOI: $10.12957 /$ teias. $\%$ Y.50069

\title{
O ENSINO E A REFORMA PROVINCIAL DE 1845: a Instrução Pública na província do Piauí (1834-1852)
}

Resumo

O presente artigo discute a Instrução Pública na Província do Piauí e sua expansão, adotando como recorte temporal o período entre os anos de 1834, com o Ato Adicional à Constituição, que pôs fim ao modelo educacional implantado com as Aulas Régias, e 1852, com a transferência da capital da Província de Oeiras para Teresina, recorte em que se assistiu a tentativas limitadas de institucionalização de uma educação pública durante a Regência e primeiros anos do Segundo Império. Metodologicamente, trata-se de pesquisa histórica de base bibliográfica que, além da literatura existente sobre o tema e a legislação vigente no período, apoiou-se na documentação pertencente ao Arquivo Público do Estado do Piauí - APEPI, sobremaneira, a documentação expedida pela Presidência da Província e pela Assembleia Provincial, o que permitiu a construção de um diálogo que possibilitou novos olhares a respeito da história da educação no período, bem como a reflexão sobre outras dimensões do tecido social local. De maneira geral, com a pesquisa, verificou-se uma lenta expansão da Instrução Pública, como consequência do pequeno interesse dos poderes públicos em seu desenvolvimento, resultando em limitados investimentos, aliado a um modelo produtivo que pouco demandava do saber formal em suas práticas cotidianas.

Palavras-chave: história; instrução pública; reforma do ensino; piauí (séc. XIX).

\section{T'EACHING AND PROVINCIAL REFORM OF 1845: Public Education in the province of Piauí (1834-1852)}

\begin{abstract}
This article discusses Public Education in the Province of Piauí and its expansion, adopting the period between the years 1834, with the Additional Act to the Constitution, which ended the educational model implemented with the Royal Classes, and 1852, with the transfer of the capital of the Province of Oeiras to Teresina, in which there were limited attempts to institutionalize public education during the Regency and the first years of the Second Empire. Methodologically, this is a historical research with a bibliographic basis that, in addition to the existing literature on the subject and the legislation in force in the period, was supported by the documentation belonging to the Public Archives of the State of Piauí - APEPI, especially, the documentation issued by the Presidency of the Province and by the Provincial Assembly, which allowed the construction of a dialogue that allowed new perspectives on the history of education in the period, as well as the reflection on other dimensions of the local social fabric. In general, with the research, there was a slow expansion of Public Education, as a consequence of the small interest of public authorities in its development, resulting in limited investments, combined with a productive model that demanded little formal knowledge in its daily practices.
\end{abstract}

Keywords: history; public instruction; public instruction; teaching reform; piauí (19th century).

\section{LA ENSEÑANZA Y LA REFORMA PROVINCIAL DE 1845: Educación pública en la provincia de Piauí (1834-1852)}

Resumen

Este artículo analiza la Educación Pública en la Provincia de Piauí y su expansión, adoptando el período comprendido entre los años 1834, con la Ley Adicional a la Constitución, que puso fin al modelo educativo 
implementado con las Clases Reales, y 1852, con la transferencia de la capital de la Provincia de Oeiras a Teresina, en la cual hubo intentos limitados de institucionalizar la educación pública durante la Regencia y los primeros años del Segundo Imperio. Metodológicamente, esta es una investigación histórica con una base bibliográfica que, además de la literatura existente sobre el tema y la legislación vigente en el período, fue respaldada por la documentación perteneciente a los Archivos Públicos del Estado de Piauí - APEPI, especialmente, la documentación emitida por la Presidencia de la Provincia y por la Asamblea Provincial, lo que permitió la construcción de un diálogo que permitió nuevas perspectivas sobre la historia de la educación en el período, así como la reflexión sobre otras dimensiones del tejido social local. En general, con la investigación, hubo una lenta expansión de la educación pública, como consecuencia del pequeño interés de las autoridades públicas en su desarrollo, lo que resultó en inversiones limitadas, combinadas con un modelo productivo que exigía poco conocimiento formal en sus prácticas diarias.

Palabras clave: historia; educación; instrucción pública; reforma docente; piauí (siglo XIX).

\section{INTRODUÇÃO}

Pesquisas que tratam da implantação e trajetórias da Instrução Pública nos primeiros anos do Império brasileiro, sobretudo, em regiões distantes dos centros econômicos e políticos do país, mesmo considerando o seu crescimento, são ainda uma empreitada desafiadora: resultado, de um lado, da má preservação de suas fontes e, por outro, das divergências na literatura sobre o tema. Entretanto, devemos reconhecer que os caminhos tomados pelas formas de escolarização no Brasil integram o conjunto de ações articuladas no processo de formação do Estado Imperial (GONDRA, SCHULER, 2008), temática sempre em pauta nas discussões políticas por todo o século XIX.

No presente artigo, procuramos colaborar no sentido de aprofundar a discussão acerca do ensino formal na Província do Piauí, tomando como marcos de atenção os anos de 1834, com o Ato Adicional à Constituição, que pôs fim ao modelo educacional implantado com as Aulas Régias, e 1852, com a transferência da capital da Província de Oeiras para Teresina, recorte em que se assistiu a tentativas limitadas de institucionalização de uma educação pública durante a Regência e primeiros anos do Segundo Império.

Para escrita, utilizamos como referências, além da literatura existente sobre o tema e a legislação vigente no período, a documentação pertencente ao Arquivo Público do Estado do Piauí - APEPI, sobremaneira, a documentação expedida pela Presidência da Província e pela Assembleia Provincial, o que permitiu a construção de um diálogo que possibilitou novos olhares a respeito da história da educação no período, bem como a reflexão sobre outras dimensões do tecido social local. De maneira geral, com a pesquisa, verificamos uma lenta expansão da Instrução Pública, como consequência do pequeno interesse dos poderes públicos em seu desenvolvimento, resultando em limitados investimentos, aliado a um modelo produtivo que pouco demandava do saber formal em suas práticas cotidianas.

\section{AS PRIMEIRAS “CADEIRAS” DE INSTRUÇÃO PÚBLICA NO PIAUÍ (1815-1834)}

Discutindo a respeito da Instrução Pública no Piauí, Alencastre (2005) salienta que esta “[...] foi a Província que mais tarde recebeu o benéfico favor da instrução. Até 1814 o que se chama instrução elementar lhe era dada empiricamente por particulares pouco habilitados, para exercerem tão importantes funções" (p. 100).

Somente por meio do Decreto de 4 de setembro de 1815 (ALENCASTRE, 2005) são criadas três Cadeiras de Primeiras Letras, instaladas na cidade de Oeiras e nas vilas de Parnaíba e 
Campo Maior, e por meio do Decreto de 15 de julho de 1818 (PIAUÍ. AHU. 3 ago. 1818), foi criada a primeira Cadeira de Gramática Latina, na cidade de Oeiras ${ }^{1}$. Ainda assim, Neves (1997) destaca que as dificuldades continuaram, pois, "[...] tamanha era a carência de pessoas idôneas, que ficaram vagas por muitos anos" (p. 42).

A dificuldade de provimento das Cadeiras de Instrução também esteve diretamente relacionada com os ordenados oferecidos aos professores. Os baixos salários e o atraso nos pagamentos contribuíram para o ocaso no preenchimento das vagas disponíveis, uma vez "[...] que pessoas habilitadas, quase sempre abastadas, não se propunham a exercer a função. Assim, as cadeiras, se providas, em pouco tempo eram abandonadas, donde as contínuas vacâncias a oferecer oportunidade a professores sem habilitação" (NUNES, 1975, p. 56), condição também encontrada em outras regiões.

Não bastasse isso, os professores públicos eram responsáveis ainda por financiar o desempenho de seu ofício com o ordenado que recebiam. Responsáveis, também, pelos meios e os materiais necessários ao funcionamento das Aulas. As escolas funcionavam em suas próprias casas e a compra do material necessário às aulas também ficavam a seus encargos, bem como as despesas com suas qualificações (CARDOSO, 2004).

Dessa forma, não causa estranheza que essas primeiras escolas não tenham obtido êxito, tendo sua curta existência atribuída, entre outros fatores, à carência de professores habilitados para ministrarem as aulas e à limitação de recursos a serem empregados no pagamento dos poucos interessados.

A vacância das Cadeiras de Instrução torna-se, assim, problema rotineiro na história piauiense, sobretudo em virtude da falta de pessoas qualificadas para preencher as vagas disponíveis. É o que pode ser observado no ofício de 1821 do Governador da Capitania, Elias José Ribeiro de Carvalho, a respeito das Cadeiras de Gramática Latina e de Primeiras Letras da cidade de Oeiras, informando que estas se encontravam vagas, atribuindo a isso o motivo de que no Piauí não havia "[...] uma pessoa que possua medianos conhecimentos para as ocupar" (apud NEVES, 1997, p. 42).

Os baixos ordenados pagos ao magistério não representaram problema exclusivo no Piauí, sendo motivo de lamento de deputados à Assembleia Constituinte de 1823, oriundos de diversas Províncias, a exemplo da Paraíba, Bahia, Ceará, Santa Catarina e Piauí, que chamavam a atenção para a insignificância do salário dos professores, "[...] tão mesquinho que ninguém se afoita a ser mestre de gramática latina, nem mesmo de primeiras letras" (MOACYR, apud PINHEIRO, 2002, p. 21).

A baixa remuneração aos docentes representa apenas um dentre tantos outros problemas enfrentados pela educação, fazendo parte de uma conjuntura política e econômica, na qual, com um discurso contraditório, os gestores da Instrução reconheciam a importância social do trabalho dos professores, mas, por outro lado, isso não correspondia a ações para melhor qualificá-los e remunerá-los.

Mesmo assim, por todo o país, o magistério público, semelhante à prática de outras funções da administração pública, foram tomados como um dos instrumentos componentes das redes de clientela e mesmo como acesso ao governo e suas benesses (SILVA, 2007). No Piauí, a exemplo

1 Cf. Alencastre (2005), a criação das Cadeiras de 1815 e 1818, somente foi possível em razão dos “[...] reiterados esforços do reverendo padre Matias de Lima Tavares". 
DOI: $10.12957 /$ teias.\%Y.50069

do que acontecia também em Pernambuco ${ }^{2}$, e apesar de suas dificuldades, o acesso ao magistério público,

[...] permitia àqueles que a ele se dedicassem o desfrute de um cargo público vitalício, independente do comando de uma chefia direta (conforme ocorria com funcionários de repartições, por exemplo); passível de ser exercido em toda a província; portador de um significativo prestígio social em meio às camadas mais modestas da sociedade, significativamente valorizado para o ingresso nas redes locais de clientela (SILVA, 2007, p. 174).

A carência de escolas e de pessoas habilitadas ao magistério, apesar de não representar um problema exclusivo no Piauí, tinha por diferencial possuir uma economia baseada na pecuária, que não demandava formação de mão-de-obra por intermédio de ensino formal. Somente a administração pública necessitava desses quadros.

Não obstante, "[...] o ensino, com os conteúdos de leitura e escrita, e até de latim, pouco interessava a uma população de vaqueiros e homens da terra. O ensino, dissociado da realidade, não oferecia atrativos ao povo, que não sentia a necessidade de tais conhecimentos" (FERRO, 1996, p. 58). Assim, de maneira geral, a população "[...] não se interessava muito em que seus filhos aprendessem a ler e a escrever. Por seu lado, os meninos temiam a escola, que não era absolutamente risonha e franca" (CHAVES, 1998, p. 33), assustando ainda pelo uso corrente de castigos físicos ${ }^{3}$. Assim, conforme Costa Filho (2006), o interesse em relação ao ensino, quando existente, "[...] era apenas desasnar as crianças e, nesse sentido, as 'escolas familiares' atendiam muito bem" (p. 127).

Em relação ao ensino no Piauí em seu período colonial e primeiros anos do Império, a literatura sinaliza para um caráter bastante pragmático, tendo o ensino escolar pouco espaço nessa organização social. Nessa sociedade, o trabalho principal não exigia um saber escolar, mas um conhecimento prático. Assim, durante os primeiros anos do Império, o quadro da educação no Piauí pouco se modificou no que se refere à Instrução Pública, uma vez serem poucos os grupos sociais que dispunham de capacidade organizativa para pressionar o Estado, com o intento à obtenção de melhorias para a educação pública.

Após a outorga da Constituição de 1824, que trouxe modificações importantes para educação no Império brasileiro, os condicionantes político-econômicos continuaram a exercer forte influência sobre o processo de organização da Instrução Pública, no qual a oferta das Cadeiras continuou a atender interesses localizados, sobretudo das elites políticas, que necessitavam destas como um mecanismo de acesso à administração pública.

Esses mesmos condicionantes também eram encontrados em outras partes do país, em que as elites dirigentes, desde tempos coloniais, optaram por restringir ao limite de seus interesses a quantidade de aulas e de professores (SILVA, 2007). Como observa Adriana Silva (2007), no concernente ao Brasil, "[...] o problema do diminuto desenvolvimento das práticas públicas de escolarização deveu-se às opções políticas das elites locais" (p. 284), submetendo a Instrução Pública ao "turbilhão da política". No Piauí, observa-se também que a estrutura de ensino, seja ela

\footnotetext{
${ }^{2}$ Cabe destacar a duradoura ligação entre o Piauí e o Pernambuco, províncias que mantiveram fortes laços econômicos e políticos entre os séculos XVII e XIX, laços que se estenderam também a organização da Instrução Pública. Cf.: NUNES, 1975; SOUSA NETO, 2005.

${ }^{3} \mathrm{O}$ modelo pedagógico utilizado baseava-se na autoridade do professor, que se valia de métodos como o bê-á-bá cantado e do uso da palmatória, esta última sendo abolida oficialmente por meio da Reforma implantada pela Lei n. 537, de 2 de julho de 1864, mas de prática encontrada ainda no século XX. A esse respeito, ver: COSTA FILHO, 2006.
} 
pública ou privada, encontrava-se ancorada em interesses das elites locais que, conforme seus desejos, criavam ou extinguiam Cadeiras de Instrução.

O movimento de criação, provimento e extinção das Cadeiras, amplamente observado neste estudo, evidenciam as conveniências destas que atendiam, muitas vezes, a interesses particulares de pais e alunos que solucionavam ou criavam interdições locais ou legais para os problemas que a eles se opunham.

Com o advento da Constituição de 1824, determinou-se a gratuidade do ensino, bem como a sua universalidade ${ }^{4}$. Contudo, essas medidas mostraram-se limitadas, dadas às dificuldades de recursos a serem investidos e à falta de pessoal qualificado e interessado no exercício do magistério. Ressalte-se que em 1824, período em que todas as atenções se voltavam para as lutas de Independência e seu desenrolar na Província, os gastos com a Instrução Pública foram de apenas 1:050\$000 réis (hum conto e cinquenta mil réis). Existiam, então, apenas três escolas de Primeiras Letras, instaladas em Oeiras, Campo Maior e Valença, e duas Cadeiras Secundárias de Latim, uma em Oeiras e outra em Parnaíba (COSTA, 1974, p. 360).

A condição da Instrução Pública foi mais agravada pela decisão do Imperador, por meio de Portaria de 22 de agosto de 1825, de adotar nas escolas das Províncias o método Lancaster ou de ensino mútuo, com o objetivo de atender a um maior número de alunos com baixos custos ${ }^{6}$. A adoção desse método representou uma tentativa simplista de solução para o problema complexo da educação. Por meio dele, pretendia-se que o professor atingisse o maior número de alunos por intermédio do uso de monitores, alunos com melhor desempenho que orientariam colegas considerados mais atrasados. Esse método, contudo, era desconhecido dos poucos professores da Província, causando embaraços não só aos professores, que o ignoravam, como aos Presidentes, a quem cabia dar cumprimento à determinação imperial.

Dessa forma, mais uma vez destacamos que a Instrução Pública continuava esbarrando em dois entraves já citados: falta de recursos financeiros e de pessoal qualificado para exercer o magistério, inibindo seu desenvolvimento.

\footnotetext{
${ }^{4}$ Nos parágrafos 32 e 33, do artigo 179, da Constituição Outorgada de 1824, encontra-se a seguinte redação: "』 32 - a instrução primária é gratuita a todos os cidadãos. \33-Colégios e universidades, onde serão ensinados os elementos das ciências, belas letras e artes". Estes mesmos princípios já se encontravam expostos no texto manuscrito de frei Francisco de Santa Tereza, que propunha, para a Constituição de 1823, instrução primária, gratuita a todas as classes de cidadãos; os elementos das Ciências, das Belas Artes, e Belas Letras que seriam ensinados nas Aulas, e Universidade; e a uniformidade do ensino público. Estes princípios foram literalmente transcritos como os artigos 32 e 33 do projeto de Francisco Gomes da Silva, o Chalaça, sem qualquer modificação imperial, e, mais tarde, foram igualmente transcritos para a Constituição Portuguesa de 1826. Cf.: CHAZZOTI. In: FÁVERO, 2001; e BONAVIDES e AMARAL, 2002. 5 Vale ressaltar que, cf. Neves (1997), neste ano somente uma Cadeira de Instrução funcionava no Piauí, a qual acreditase que estivesse se referindo a da cidade de Oeiras. No entanto, não foi possível confirmar essa informação. Para Neves, nesse período, o Piauí “[...] não tinha nem cultura política, nem cultura literária. Uma afirmação diz tudo: em 1824 funcionava na província uma única escola de primeiras letras!” (p. 40). Mas, considerando a precisão da informação dada por Costa sobre os gastos com Instrução Pública e lembrando que estes gastos se resumiam ao pagamento dos professores, entende-se que o número de cadeiras em funcionamento apontado por este seja mais próximo da configuração histórica vivenciada no período.

${ }^{6}$ Por decreto de $1^{\circ}$ de março de 1825 , criou-se no Rio de Janeiro a primeira Escola de Ensino Mútuo do país com o objetivo de propagar este sistema de instrução que, por meio de ordem ministerial de 29 de abril, exigia que cada província do Império enviasse um soldado que seguiria as lições desta escola, para em seguida propagá-la na província de origem. Essas medidas não foram dadas seguimento e jamais foi preparado um edifício para a realização dessas aulas. Cf. Almeida (2000, p.57), “[...] o sistema de ensino mútuo, devido ao celebre Joseph Lancaster, tinha sido trazido da Índia para a Inglaterra pelo Dr. André Bell. Este método era conhecido na Europa desde o século XVI e recomendado por Erasmo; a aplicação foi feita com grande sucesso em São Ciro pela Sr ${ }^{a}$. Maintenon. No século XVIII, a cidade de Orleans as escolas anexas ao Hospício da Piedade também o adotaram; a partir de 1814, o ensino mútuo se estendeu rapidamente na França, Suíça, Rússia e Estados Unidos, onde o próprio Lancaster o propagou".
} 
O Decreto das Escolas de Primeiras Letras, lei de 15 de outubro de 1827, ainda regulamenta outros pontos da Instrução Pública, a qual o Piauí também se encontrava submetido. Por meio desse, o governo imperial sinalizava com uma preocupação em ampliar o acesso escolar ao tornar obrigatória a instalação de escolas de Primeiras Letras em todas as cidades, vilas e lugares mais populosos do Império. No entanto, o ensino ainda não era obrigatório e estava destinado apenas aos cidadãos livres.

Estabeleceu ainda, mesmo de maneira precária, um currículo a ser ofertado aos alunos, determinando que,

os professores ensinarão ler, escrever, as quatro operações de aritmética, prática de quebrados decimais e proporções, as noções mais gerais de geometria prática, a gramática da língua nacional, os princípios de moral cristã e de doutrina da religião católica e apostólica romana, proporcionadas à compreensão dos meninos; preferindo para o ensino da leitura a Constituição do Império e História do Brasil (BRASIL, 1878a, p. 71).

No caso da Instrução de meninas, o Decreto exclui as noções de Geometria e limita a instrução Aritmética às quatro operações, mas acrescentava o ensino de "[...] prendas que servem à economia doméstica" (BRASIL, 1878a, p. 71), indicando projetos educacionais e sociais diferenciados de acordo com o gênero dos alunos.

A respeito do currículo destinado às meninas, deve ser observado, portanto, que ele deixa transparecer o lugar social que se destinava a elas, o espaço do privado, pois, a preocupação com o ensino feminino não se relaciona a uma proposta deliberada de manter as mulheres com um nível de instrução inferior ao dos homens, mas de oferecer-lhes a instrução necessária e conveniente ao espaço que lhes era destinado, levando-as a assumir suas funções de donas de casa, nos cuidados com esposos e filhos.

Ainda no que se refere ao currículo, como observa Adriana Silva (2007) em estudo sobre as práticas de escolarização em Pernambuco, “[...] eram os professores que decidiam, na prática, o que ensinariam, a quem o fariam, aonde queriam ou podiam fazê-lo e quais matérias e recursos usariam para tais fins" (p. 163). Semelhante condição também era encontrada no Piauí, possível graças a uma estrutura de acompanhamento e fiscalização frágil e, muitas vezes, conivente. $\mathrm{O}$ Decreto previa ainda a disponibilização de edifícios, à custa da Fazenda Pública, para as atividades das aulas de ensino mútuo. No entanto, durante a maior parte do período provincial, por todo o Império, "[...] a vinculação dos estudantes era com seus professores, e não com os espaços físicos nas quais as aulas aconteciam" (SILVA, 2007, p. 74). Assim, as aulas de Primeiras Letras e Secundárias eram ministradas no local onde estivesse o próprio professor, preferencialmente em suas residências (SILVA, 2007).

Frente ao limitado alcance da Instrução Pública em todo o país, a Coroa transfere, em 1834, a responsabilidade sobre a Instrução Pública de Primeiras Letras e Secundária para as Províncias, inclusive no Piauí, tema discutido na seção seguinte.

\section{A INSTRUÇÃo PÚBLICA E A REFORMA PROVINCIAL DE 1845}

O Ato Adicional à Constituição de 1834 pôs fim ao modelo implantado com as Aulas Régias, substituídas por outro sistema de ensino, caracterizado pela descentralização, considerando que tanto o ensino de Primeiras Letras quanto o Ensino Secundário ficaria a cargo das Assembleias Legislativas provinciais. Por meio desse Ato, determinou-se que caberiam às Províncias os encargos relativos à Instrução Pública. Conforme seu artigo $10^{\circ}, \S 2$ : 
Compete às mesmas Assembleias [Legislativas Provinciais] legislar (...) sobre instrução pública e estabelecimentos próprios e promovê-la, não compreendendo as faculdades de medicina, os cursos jurídicos, academias atualmente existentes, e outros quaisquer estabelecimentos de instrução que para o futuro forem criados por lei geral (BRASIL, 1878b).

A descentralização propiciada pela normativa conferiu maiores poderes às Províncias, permitindo-lhes a gerência de seus próprios sistemas de ensino. Mas, se por um lado, representava uma maior autonomia às Províncias para legislarem sobre o que esperavam da educação, adequando-as às necessidades de cada uma, por outro lado acarretou prejuízos, uma vez que o governo central, que deveria concorrer com as Províncias para a oferta da Instrução, apenas transferiu atribuições, eximindo-se de responsabilidades e deixando a cargo dos grupos locais o exercício ou não da educação.

Em relatório de 1852 sobre a Instrução Pública em diversas províncias do Norte do Brasil, encaminhado ao Ministro do Império José da Costa Carvalho, o poeta Antonio Gonçalves Dias lamentava que a autonomia administrativa concedida às províncias e suas assembleias, por meio do Ato Adicional de 1834, não tenha sido algo positivo em relação à Instrução Pública, que ficou “[...] sujeita a todos os entreveros decorrentes das disputas políticas locais, dentre eles, as decisões referentes aos orçamentos e gastos do governo provincial, aos serviços públicos e empregos a serem criados ou suprimidos e aos salários dos funcionários” (SILVA, 2007, p. 237).

Gonçalves Dias ainda destacou que:

A legislação provincial relativa à instrução, os seus efeitos até hoje, a previsão do que será no futuro pelo que tem sido no passado, dezessete anos enfim de experiências baldadas bastam, segundo penso, para nos convencerem que em matérias de instrução - nada, absolutamente nada se pode esperar das Assembleias Provinciais (DIAS, apud SILVA, 2007, p. 235).

Assim, o Piauí e outras províncias que dispunham de um aporte menor de recursos, eram obrigadas a conviver com avanços e recuos da Instrução Pública, obedecendo às oscilações de suas rendas e à instabilidade do temperamento e prioridades de suas autoridades administrativas. Alencastre (2005), ao se referir ao ano de 1834, esboça quadro não muito animador sobre a Instrução Pública piauiense, revelando que eram

providas as cadeiras com inábeis professores, porque homens inteligentes e ilustrados não se queriam sujeitar à sorte precária do magistério - como que a instrução corria à revelia, árida e improfícua. As cadeiras de instrução maior viviam em completo abandono, e os que as aceitavam, ou não eram habilitados, ou mal cumpriam com seus deveres (2005, p. 101).

O quadro de carência evidenciado por Alencastre é percebido também pelo fato de que nesse mesmo ano existia no Piauí um total de quatorze Cadeiras de Primeiras Letras, das quais duas Cadeiras pelo método mútuo na cidade de Oeiras. No entanto, desse total, sete encontravam-se sem professores (COSTA, 1974), reafirmando um problema que acompanhava a história da Instrução Pública local.

Cabe destacar que em resposta à fala do Presidente da Província na abertura dos trabalhos da primeira legislatura da Assembleia Legislativa Provincial, em 18357, Padre Marcos de Araújo

7 O ano de 1835 marca o início dos trabalhos da Assembleia Provincial do Piauí, criada pela lei de 12 de agosto de 1834. Cf. Costa (1974), em seu primeiro ano de funcionamento, foram decretadas vinte e seis leis provinciais, sendo 
Costa, como deputado, reconhecia esforços no sentido de criar e prover as Cadeiras de Instrução da Província, "[...] para que, servidas de Mestres hábeis as Cadeiras nela criadas se difund[issem] com rapidez as luzes de que necessita[vam] seus habitantes" (PIAUÍ. APEPI. 15 maio 1835).

À essa época, destaca o Presidente, “[...] acham-se criadas nesta província três Cadeiras de Gramática Latina, convêm a saber, uma na Capital, outra na Vila de Campo Maior, e outra na de Parnaíba, e todas providas com ordenados de $600 \$ 000$ réis" (PIAUÍ. APEPI, 04 maio 1835) e mais quatro cadeiras, em Oeiras, de Retórica, Filosofia, Francês e Geometria, que se achavam vagas por falta de professores.

Quanto ao ensino de Primeiras Letras, em Oeiras existiam duas Cadeiras pelo método mútuo, uma para meninos e outra para meninas, com ordenados de $400 \$ 000$ réis. Esta última encontrava-se vaga. Existiam ainda doze Cadeiras de Primeiras Letras, pelo método simples, nas vilas de Jaicós, Valença, Príncipe Imperial, Jerumenha, Parnaguá e Capela das Barras, das quais três encontravam-se vagas.

Apesar da condição precária na qual ainda se encontrava, a documentação compulsada indica que o ano de 1837 foi de significativa importância para a Instrução Pública piauiense em razão do provimento da maioria das Cadeiras de Primeiras Letras e Secundárias existentes. Isso talvez tenha se dado como resultado da melhoria nos vencimentos dos professores, que desde 1836 passaram a ser arbitrados em $300 \$ 000$ réis anuais (PIAUÍ. APEPI, 20 ago. 1836).

Nesse ano, com o juramento e posse de oito mestres e professores ${ }^{8}$, ocuparam-se algumas das Cadeiras de Instrução que se encontravam vagas, mesmo que criadas desde 1829, o que demonstra também que as aulas públicas de primeiras letras não se constituíram num privilégio da capital ou das vilas maiores, funcionando também em comunidades distanciadas de Oeiras e/ou pouco populosas.

Entre essas, verifica-se inclusive o provimento de uma Cadeira de Primeiras Letras para meninas na vila de Campo Maior, pelo método mútuo, ocupada por Dona Maria Ferreira do Nascimento que, conforme indica a documentação consultada, foi a primeira professora a assumir o magistério público na Província do Piauí (PIAUÍ. APEPI, 13 maio 1837), um significativo passo na história da Instrução Pública.

Mas o provimento dessas Cadeiras de Instrução, se por um lado representa um ganho quantitativo, por outro parece não ter sido acompanhado de uma melhora qualitativa no ensino ofertado, dadas as limitações que continuaram a se manifestar neste cenário.

Em mensagem do Presidente da Província à Assembleia Legislativa Provincial, no ano de 1838, o Barão da Parnaíba informava aos deputados das dificuldades experimentadas na Instrução Pública. Segundo destacava:

\footnotetext{
que a primeira destas diz respeito às aulas de filosofia da Província, ao mandar que fosse adotado nas referidas aulas os "compêndios de lógica, metafísica e ética" de Ponelli e traduzidos por João Candido de Deus e Silva. Essa lei foi sancionada e publicada pelo Barão da Parnaíba sob o número 01, em 29 de maio de 1835. A respeito dessa lei, acreditase que resultou de iniciativa de Padre Marcos, por ser, juntamente com José Monteiro de Sá Palácio, membro da Comissão de Instrução Pública que propôs o projeto de lei e por sua familiaridade com a temática.

${ }^{8}$ Cf. PIAUÍ. APEPI. Livro de posses da capitania. Sala do Poder Executivo, 1814-1859. São estes: Antonio João Baptista Ferreira, professor de Gramática Latina em Oeiras; José Ferreira Guimarães, professor de Primeiras Letras na vila do Poti; Segundo Manoel da Rocha, professor de Primeiras Letras na vila de Jaicós; Padre Inácio Ribeiro de Melo, professor de Gramática Latina na vila de Príncipe Imperial; Maria Ferreira do Nascimento, professora de Primeiras Letras de meninas na vila de Campo Maior; Leocádio Costa Meirelles, professor de Primeiras Letras em Piracuruca; Carlos Irineu da França, professor de Gramática Latina em Parnaguá; Francisco Thomas da Silva, professor de Primeiras Letras em Príncipe Imperial.
} 
Não tomarei a conduta em geral dos Professores, que se acham na Província entregues do importante encargo de educar a Mocidade, e antes direi que alguns deles são pouco hábeis e capazes tanto por seus irregulares costumes, como pela fraqueza de seus conhecimentos; porém forçoso foi empregá-los, visto que foram os únicos a concorrerem ao Emprego do Magistério e em uma Província, a onde data de poucos anos a Instrução Pública, raros são os indivíduos dela que se possam apresentar com todos os requisitos próprios e necessários para dirigir a Juventude na carreira das Letras, e bons costumes, sendo preciso aproveitar os que vêm de fora, que seguramente não são os de melhor nota, e em tão apertada colisão não pode haver escolha que permita ao Governo usar da preferência. (PIAUÍ. APEPI. 9 jul. 1838).

Nesse fragmento, ressalta-se mais uma vez a carência de pessoal qualificado para ocupar as Cadeiras de Instrução, bem como a consciência do gestor quanto a relação entre nível salarial, a qualificação dos professores e a consequente qualidade do ensino. Ele reconhece que os baixos salários pagos afastavam aqueles mais qualificados ao exercício do magistério. Lembre-se ainda que, mais que uma opção, o provimento dos professores se fez imposto pela própria legislação, o que tornava preferível tê-los em seus quadros, apesar do pouco preparo, que deixar as Aulas sem funcionar.

A Assembleia Provincial, em resposta a essa situação, apenas lamentava a pouca qualificação dos professores, não sinalizando com nenhuma medida ou ação a ser tomada de forma que resolvesse ou minimizasse o problema (PIAUÍ. APEPI. 10 ago. 1838). A consciência do problema não significou a criação de ações que o combatesse, muito pelo contrário, revelou apenas que isso era tão evidente que não podia ser negado.

No ano anterior, 1837, os "irregulares costumes" de alguns professores já tinham sido alvo da atenção da Assembleia. Como dito, apesar da existência de regras a serem atendidas, os professores tinham grande autonomia na condução das aulas, decidindo seu calendário de festas, horários das aulas e seus intervalos, métodos de ensino e mesmo conteúdo. Essa autonomia do professor, fruto da incapacidade da administração pública de acompanhar o funcionamento das aulas, gerava muitas vezes reclamações contra estes. Dentre essas queixas, destaca-se a reclamação quanto à regularidade e o acompanhamento das aulas, o que motivou a Assembleia Provincial a aprovar lei estabelecendo que “[...] os professores das escolas primárias, bem como de Latim e Francês, são obrigados a assistir pessoalmente as lições diárias dos alunos, não podendo ser substituídos sem licença do governo na cidade e dos prefeitos nas vilas" (PIAUÍ. APEPI. 20 set. 1837).

De maneira geral, os mecanismos de acompanhamento e fiscalização das Aulas Públicas eram muito frágeis em todo o Brasil da primeira metade do século XIX. Por mecanismos de acompanhamento e fiscalização das Aulas, até a Independência, a preocupação, em geral, era observar apenas a conduta pessoal do professor, no qual o Estado, por meio da Real Mesa Censória, recorria a informações do pároco, do chefe de polícia e dos pais dos alunos para conferir o cumprimento das obrigações dos professores, que recaíam mais sobre suas práticas pessoais que sobre suas qualidades profissionais (CARDOSO, 2004).

Após a Independência, os professores estavam sujeitos às Inspeções das Câmaras Municipais, de quem dependiam para obter os atestados que lhes garantiam receber seus ordenados, cuja conduta dos professores e a rede de relações em que se inseriam eram de grande importância para sua obtenção. Conforme relatório do Presidente da Província, no Piauí, os 
professores cumpriam com suas principais obrigações (PIAUÍ. APEPI. 10 ago. 1838), apesar da existência de críticas à conduta pessoal e aos frágeis conhecimentos de alguns professores.

Para garantir o recebimento de seus atestados, em geral, bastava que nenhuma reclamação fosse feita contra o professor, considerado pela comunidade, dessa forma, como um bom professor. Nesse sentido, era importante para o professor manter os pais dos alunos satisfeitos com o seu trabalho e sua conduta pessoal, e assim preservar seus alunos e sua Aula. Destaque-se que em uma região em que os laços de solidariedade familiar eram muito estreitos, ter um pai de aluno insatisfeito com seu trabalho ou sua conduta implicava em séria ameaça à manutenção de seu emprego.

Os professores da Província se tornaram, assim, vulneráveis à opinião pública, ameaça permanente à continuidade de seu trabalho, considerando que a conduta moral do professor era item fundamental para o desempenho do magistério. Desta maneira, a necessidade de não chamar atenção sobre si, e assim não ferir interesses ou orgulho de alguma liderança política local, fez surgir aulas despolitizadas e professores recatados, fórmula que ajudava a manter a Aula pública funcionando, modelo também encontrado em outras regiões do Brasil ${ }^{9}$. Também deve ser destacado que a fiscalização do andamento das aulas era mais frágil do que o apresentado na mensagem de 1838, uma vez que o tom do discurso sobre a eficiência da fiscalização das Aulas públicas muda na mensagem de 1843, denunciando o descaso das instâncias fiscalizadoras. Segundo o mesmo Presidente,

A lei de 22 de setembro de 1837 , no artigo $6^{\circ}$, encarregou os fiscais de vigiar se seus professores cumprem com suas obrigações e de darem parte à Câmara respectiva das omissões que observasse para esta as ter em vista na ocasião de eles passar os atestados para a cobrança dos ordenados; mas em alguns lugares esta incumbência não é satisfeita, e as Câmaras a respeito são condescendentes, do que resulta que muitos professores às vezes deixam de assistir pessoalmente as aulas, como expressamente lhes é determinado pelo artigo $1^{\circ}$ da mesma lei, mandando que as dirijam os alunos mais adiantados, que certamente não podem manter a ordem nelas, outras vezes a seu arbítrio transformam em feriados dias úteis, em prejuízo do ensino da mocidade (PIAUÍ. APEPI. 7 jul. 1843).

O fragmento acima denuncia a negligência de alguns professores no cumprimento de seu ofício, atribuindo a alunos suas responsabilidades ou deixando de ministrar as aulas previstas, o que agravava bastante a qualidade do ensino ministrado e a credibilidade atribuída aos professores envolvidos.

Esse quadro gerou tentativas de intervenções. O pouco empenho na fiscalização das atividades dos professores e de outros ramos do interesse público nas vilas fez com que Padre Marcos, na condição de Presidente da Câmara de Jaicós, com vistas a estimular um maior empenho do fiscal da Vila, solicitasse à Assembleia Legislativa Provincial uma gratificação especial ao fiscal. A gratificação tinha a intenção de "[...] animá-lo a uma exata e rigorosa fiscalização das infrações das posturas e para a verificação das multas que deverão ser impostas” (PIAUÍ. APEPI. 5 jul. 1845).

\footnotetext{
${ }_{9}$ Cf. Silva (2007, p. 205), considerando a Província de Pernambuco, “[...] do ponto de vista das comunidades que demandaram e nas quais funcionaram as aulas públicas de primeiras letras, a possibilidade de tê-las e/ou mantê-las, dependia, em larga medida dos graus de imersão dos professores públicos no turbilhão da política, ou seja, se eles estavam ou não em harmonia com os potentados locais e provinciais”. Guardadas as devidas proporções, o exercício no magistério público na Província do Piauí, na primeira metade do século XIX, também dependia da harmonia dos professores com os grupos dirigentes locais.
} 
Assim, apesar de algum avanço com o provimento de Cadeiras que tinham sido criadas e não ocupadas, observa-se a continuidade da precariedade da Instrução Pública. Conforme se encontra na mensagem de 1843, "“...] a instrução acha-se em grande atraso nesta província, sendo disso principal causa a pouca aptidão dos professores, a quem está confiada importante tarefa de educar a mocidade" (PIAUÍ. APEPI. 7 jul. 1843) e a falta de recursos a serem destinados não somente ao ensino como nas mais diversas áreas de interesse público.

No entanto, mesmo considerando a educação como "a base da civilização dos povos e germe da moral" (PIAUÍ. APEPI. 13 jul. 1837) e a "base manancial da felicidade dos Estados", a administração piauiense entendia que as ações em favor da Instrução deveriam ser feitas "sem aumentar dispêndios" (PIAUÍ. APEPI. 1840). Isso é ressaltado em diferentes registros oficiais consultados, evidenciando que não era falta de consciência que contribuía para a manutenção dessa precariedade, mas a falta de ações.

Mas, ao deter-se um pouco mais ao final da década de 1830 e primeiros anos da década seguinte, verifica-se que as recomendações em não se aumentar gastos com a administração, inclusive no que se refere à Instrução, possuía como motivador a severa crise política e financeira na qual o Piauí mergulhou, em virtude do combate travado pelo Governo contra os insurretos balaios. Por toda a primeira metade do século XIX, o Piauí foi marcado por uma série de conflitos sócio-políticos que se refletiram no andamento e organização da Instrução Pública, o que foi intensificado com a Balaiada.

Sobre esse período, a documentação disponível no APEPI indica nova crise na já frágil Instrução Pública da Província, resultado das dificuldades de provimento e mesmo o abandono de muitas Cadeiras de Instrução por parte de seus professores. Esse abandono resultou, por um lado, dos baixos salários que continuavam a ser pagos ao magistério; por outro, devido à convulsão provocada pela Balaiada, que se alastrava pela Província, difundindo temores e reações diversas.

Mesmo assim, para o ano de 1840, contava a Província com duas Cadeiras de Instrução Secundária (Latim e Francês) em Oeiras e cinco Cadeiras de Primeiras Letras, em Oeiras, Parnaíba, Parnaguá, Príncipe Imperial e São Gonçalo do Amarante (ALMEIDA, 2000), quadro afetado pelo clima tenso vivido no período. Ainda em 1840, o Presidente da Província, por meio de mensagem encaminhada à Assembleia, informava que o estado de agitação em que se encontrava a Província obrigou muitos professores a abandonarem suas Aulas e embrenharem-se na luta, trocando a palmatória pelo fuzil (PIAUÍ. APEPI. 1840), em um período também marcado por um grande déficit fiscal, resultado da queda da arrecadação do dízimo cobrado sobre o gado vacum e cavalar, principal fonte de receita da Província, e as pesadas despesas de custeio para fazer funcionar sua força armada, em combate contra os rebeldes balaios.

Assim, frente à crise, o Barão da Parnaíba, ao alertar que "[...] achando-se exauridos os cofres públicos desta Província pelas extraordinárias e avultadíssimas despesas pela diuturna luta" e sem saber como "preencher este vácuo [nas receitas]" (PIAUÍ. APEPI. 1840), conclama a população a concorrer para as despesas da guerra de acordo com suas posses. Nesse sentido, não é de todo estranho que as preocupações e investimentos com a Instrução sejam renegados a um segundo plano, sobretudo por ser área da administração pública das mais suscetíveis à contenção de recursos quando de oscilações das receitas.

Ao fim das lutas de guerrilha que caracterizaram a Balaiada, a Província estava praticamente sem escolas, das quais, segundo Itamar Brito $(1996)^{10}$, resumiam-se apenas à existência de algumas

${ }^{10}$ Em balanço de como se encontava a Instrução na Província em 1844, Nunes (1975), faz mensão ao aparecimento de um grande número escolas particulares sob o amparo dos fazendeiros abastados, localizadas em maior número na zona rural que nas sedes municipais. Localiza o registro de nove escolas particulares em Valença, sete em Barras, três 
escolas particulares. Entre essas, pode ser destacada a escola de Boa Esperança, localizada no Centro-Sul da Província, consolidada como a maior e mais importante escola de Primeiras Letras e de Instrução Secundária no Piauí, na primeira metade do século XIX (SOUSA NETO, 2005).

Sufocada a Balaiada, continuava a Instrução Pública a conviver com a falta de professores e carência de recursos, contando, no ano de 1842, com o registro de 268 alunos matriculados nas Cadeiras de Primeiras Letras (PIAUÍ. APEPI. 4 out. 1842) ${ }^{11}$. Em 1844, a situação pouco se tinha alterado. Contabilizavam-se na Província 21 Cadeiras de Primeiras Letras (18 do sexo masculino e três do feminino) (COSTA, 1974). No ano seguinte, o número de Cadeiras cai para 19 e um total de 381 alunos matriculados (16 Cadeiras para o sexo masculino, com 340 alunos, e três para o sexo feminino, com 41 alunas) (NUNES, 1975).

As dificuldades por que passava a Instrução Pública, em especial a secundária, na qual “[...] os alunos não recebem aquela instrução que era de se esperar” (PIAUÍ. APEPI. 7 jul. 1843), também podem ser ilustradas com a distribuição de Cadeiras de Ensino Secundário no ano de 1844, resumindo-se a sete Cadeiras de Latim, das quais uma desocupada, assim distribuídas: quatro em Oeiras, duas em Parnaguá e uma em Príncipe Imperial. Em 1845, foram extintas as cadeiras existentes nestas duas últimas, em uma época na qual a Instrução "[...] não dispunha ainda de recursos suficientes para atender a todas as urgências do serviço público" (COSTA, 1974, p. 451).

Entretanto, conforme Brito (1996), o ano de 1845 marcou um novo momento da educação no Piauí, chamado de "Período de Estruturação", com a posse de Zacarias de Góis e Vasconcelos como Presidente da Província. Nesse mesmo ano, a Assembleia Provincial aprovou Decreto em 26 de setembro, que foi sancionado pelo Presidente como a Lei n. 198, de 04 de outubro. Por meio desta lei, realizou-se profunda reforma na Instrução Pública no Piauí.

Segundo Zacarias de Góis, com essa nova reforma fortalecia-se a ação do Presidente sobre o ensino, que ficava sujeito a uma direção uniforme, além de criar Cadeiras de Primeiras Letras apenas em lugares que oferecessem possibilidade de boa frequência e extinguir Cadeiras de ensino primário que não satisfizessem as condições exigidas pela legislação.

A exigência de boa frequência previa que somente existiriam Cadeiras de Instrução Primária "[...] para meninos nas cidades, vilas e povoações da Província, onde as possam habitualmente frequentar quinze alunos, e para meninas haverá naquela cidade e vilas em que possam ser habitualmente frequentadas por dez alunas" (PIAUÍ. APEPI. 4 out. 1845). No ano seguinte à lei, "[...] funcionavam 18 escolas públicas para o sexo masculino de ensino primário, com 598 alunos, e três do sexo feminino, com 59" (NUNES, 1975, p. 50).

Essa mesma lei ainda criou o primeiro estabelecimento público de Instrução Secundária da Província, o Liceu, na cidade de Oeiras ${ }^{12}$. Conforme seu artigo $10^{\circ}$, “[...] haverá também na Capital para instrução secundária um Liceu com as seguintes Cadeiras: $1^{a}$ Latim; $2^{a}$ Francês; $3^{a}$ Inglês; $4^{a}$

em Piracuruca, duas em Príncipe Imperial, sete em Parnaguá. Nunes acredita ainda que provavelmente todas as vilas possuíam escolas particulares. Cf.: COSTA FILHO, op. cit., o surgimento de colégios particulares, sejam de Primeiras Letras ou sejam Secundários, não representa um fenômeno restrito ao Piauí, mas uma tendência de todo o Império. No entanto, ainda segundo o autor, o ensino elementar permaneceu como uma tarefa própria das famílias, através das "escolas familiares", mesmo entre famílias mais abastardas.

11 Por meio dos mapas de matrículas do ano de 1842, contam-se 268 matriculados. Cabe destacar que estes números não contemplam as vilas Campo Maior, Príncipe Imperial, Jaicós e Marvão. Considerando, no entanto, que os alunos matriculados por turma pouco ultrapassavam uma dúzia de alunos, acredita-se ser o número de 300 matriculados um número razoável para a época.

12 No Brasil, a partir de 1835, o ensino secundário passou a reunir as Aulas ou Cadeiras avulsas em estabelecimentos de Instrução Secundária denominados de liceus. No entanto, deve ser lembrado que desde 1825 havia uma proposta aprovada pelo governo de implantar um liceu em Pernambuco. A este respeito, ver: Cardoso (2004). Cf. Costa Filho (2006), o Liceu somente ganhou maior regularidade de funcionamento a partir de 1850.

Revista Teias v. $22 \cdot$ n. $65 \cdot$ abr./jun. 2021 
Geometria e Aritmética; $5^{a}$ Geografia e História; 6 ${ }^{a}$ Retórica e Poética; $7^{a}$ Filosofia Racional e Moral" (PIAUÍ. APEPI. 4 out. 1845) ${ }^{13}$.

Mesmo criado o Liceu, o sistema de Cadeiras isoladas continuou a vigorar. Os alunos permaneceram a organizar seus estudos segundo interesses e conveniências, enquanto o ensino Secundário continuava a representar apenas preparatório para os exames de ingresso aos cursos superiores.

Mesmo assim, a criação do Liceu trouxe algumas modificações na estrutura de ensino da Província. Entre essas, a extinção de uma das Cadeiras de Primeiras Letras de Oeiras e quatro Cadeiras de Latim (em Parnaguá, Príncipe Imperial, Campo Maior e Parnaíba), ficando apenas uma em Oeiras, que passou a fazer parte do Liceu. Aos professores que tiveram suas Cadeiras extintas, como determinava a Lei em seu artigo 12, cabiam duas opções, escolher prover alguma Cadeira vaga ou a demissão.

Apesar de o Liceu ter sido criado na administração de Zacarias de Góis, este, no entanto, "pouco fez para a sua efetivação", o que pode ser verificado ao se observar que durante seu governo, que se estendeu de 28 de julho de 1845 a 07 de setembro de 1847, “[...] funcionou apenas a Cadeira de Latim que já encontrou provida e fez também a nomeação de professor para a de Francês, já em fins de seu governo, de forma a só entrar em exercício no ano imediato já noutra administração" (NUNES, 1975, p. 51).

A Lei n. 198 traz algumas outras novidades. Uma delas consta em seu artigo $1^{\circ}$, que diz respeito à instituição dos Diretores de Instrução Pública, a quem cabia executar as ordens previstas na lei, prestar contas ao Presidente da Província sobre o andamento das escolas, bem como zelar pela sua melhoria. O cargo era acumulado pelos juízes de direito de cada comarca, explicitando uma próxima relação entre as dimensões jurídico-administrativas e educacional.

Essa lei cria conjuntamente os cargos de vice-diretor e censores. A estes últimos caberia fiscalizar as escolas e acompanhar mais rigorosamente os professores, fazendo-lhes as devidas advertências, como estabelece seu artigo 38, bem como enviar aos Diretores mapas dos alunos matriculados nas escolas, apresentando sua assiduidade, seus progressos e talentos, como definiu o artigo 39. Sobre o regime das aulas, a Lei determinava ainda que as aulas aconteceriam nos dois turnos para o ensino primário e em apenas um turno para o ensino secundário, com feriados às quintas-feiras das semanas em que não houvesse dia santo ou feriado nacional e férias de 8 de dezembro a 6 de janeiro de cada ano.

Admitia-se também nas escolas de Instrução Primária “castigos físicos moderados", como determinava o artigo 36, prática abolida oficialmente por meio da Reforma implantada pela Lei n. 537, de 2 de julho de 1864, embora seja possível encontrar variados registros de seu uso ainda no século XX.

Até então, as punições a alunos eram previstas, mas, como determinava o Decreto de 15 de outubro de 1827, elas deveriam ser aplicadas pelo método de Lancaster, que estabelecia uma hierarquia de recompensas e punições a serem aplicadas. Entre as recompensas, destacam-se a

\footnotetext{
${ }^{13}$ Cf. Nunes (1975), a cadeira de História e Geografia somente foi provida no começo de 1848, pelo Dr. Cândido Gil Castelo Branco que se propusera compendiar, para uso de seus alunos nas aulas que lhes ministrava, as teorias e opiniões de Balbi, iniciativa imediatamente aprovada pelo governo provincial. Observa-se que o provimento das Cadeiras do Liceu não eram necessariamente supridas por meio de concurso público, como era obrigatório para o Ensino de Primeiras Letras, pois, conforme a Lei n. 198, de 04 de outubro de 1845, em seu art. 14, “[...] as cadeiras de instrução secundária serão interinamente ou vitaliciamente providas pelo Presidente, independentemente de Concurso; as de instrução primária serão postas em concurso, publicado em toda a Província três meses antes, pelo menos, de seu provimento". Lembre-se ainda que para o provimento das Cadeiras, os pareceres dos examinadores além do quesito aptidão, também contemplavam o quesito "moralidade" dos candidatos (art. 17).
} 
possibilidade de tornar-se monitor e a distribuição de prêmios. Entre as punições, estabelecia-se que o aluno infrator poderia ficar em quarentena em um banco, ou isolado em uma sala durante a aula; poderia ainda ser obrigado a permanecer em sala após o final dos exercícios, ou repetir por escrito ou em voz alta a infração cometida, bem como registrar seu nome em um livro negro e, a mais grave, a expulsão do aluno (BASTOS, In: STEPHANOU, 2005, p. 41-42).

Nota-se que o método de Lancaster não faz referências ao uso de castigos físicos impostos aos alunos. O uso de punições pelo método de Lancaster não atingiu os resultados esperados, vindo a nova lei apenas a regular uma prática corriqueira nas Aulas públicas.

A Lei n. 198 ainda fixou novos ordenados ao magistério. $400 \$ 000$ réis anuais aos professores de Primeiras Letras da Capital e 350\$000 réis para os professores das demais escolas; $500 \$ 000$ réis aos professores de Inglês e Francês e $600 \$ 000$ réis aos demais professores de Instrução Secundária. Todos eles faziam jus à gratificação por todo aluno aprovado em exame de aproveitamento, com $10 \$ 000$ réis por aluno de Primeiras Letras e $20 \$ 000$ por aluno de Instrução Secundária.

Outro ponto normatizado refere-se às Câmaras Municipais, que deveriam fornecer recursos para aquisição de material de estudo (papel, pena e tinta) para alunos pobres. Anteriormente a esta lei, encontram-se medidas isoladas no sentido de auxiliar os estudos de alunos mais carentes, como por exemplo, a Resolução da Assembleia, sancionada como Carta Lei n. 81, de 17 de setembro de 1838, que determinava que o Presidente da Província forneceria anualmente ao professor de Primeiras Letras de Oeiras “[...] 6 resmas de papel almaço, 4 dúzias de lápis, quinhentas penas e 5 aparelhos de tinta para serem distribuídos à discrição do mesmo professor pelos meninos mais indigentes, que frequentarem sua aula" (PIAUÍ. APEPI. 17 set. 1938).

Ponto importante a ser ressaltado na Lei n. 198, refere-se a seu capítulo 8. Sob título "das escolas particulares e pensões", estabelece que "[...] qualquer indivíduo pode, com licença do Diretor, abrir escola particular", como determinava seu artigo 40, ou ainda casa ou pensão para alunos, a qual o Diretor "[...] concederá depois de certificado da moralidade, aptidão do sujeito e conveniência do seu plano", conforme o artigo 41. Essas casas, contando com mais de cinco alunos, recebia o administrador a gratificação de $20 \$ 000$ réis anuais por cada aluno, até o limite de vinte alunos e mais $10 \$ 000$ réis por cada aluno excedente, sendo que as "[...] gratificações [eram] pagas pelos Cofres Públicos, a vista de atestados do Diretor", como determinava seu artigo 42.

Nesse sentido, a título de exemplo e analisando o disposto pelo texto legal, observa-se que o então Vice-presidente da Província e Presidente da Câmara de Jaicós, Padre Marcos de Araújo Costa, por conta da escola que mantinha em sua fazenda, a escola de Boa Esperança, na vila de Jaicós, se encaixava bem no perfil que determinava a lei. Dado o lugar social ocupado por Padre Marcos, seguramente ele não teria dificuldades para comprovar sua aptidão e moralidade e obter autorização para o funcionamento de sua escola que, aliás, já funcionava desde 1820. Sua escola preenchia os requisitos estabelecidos em lei provincial, o que corroborou, sobremaneira, com o prestígio dessa e de seu proprietário no cenário educacional do século XIX. ${ }^{14}$

Considerando ainda que em 1850 Boa Esperança contava com 40 alunos (PIAUÍ. APEPI. 3 jul. 1851), Padre Marcos faria jus, àquele ano, pelo menos $600 \$ 000$ (seiscentos mil réis) a serem pagos pelos Cofres Públicos. Contudo, o presente argumento fica posto como possibilidade, uma vez que não foram encontrados registros de recebimento de recursos públicos por parte de Padre

${ }^{14}$ A respeito, ver: SOUSA NETO, 2005. 
Marcos, posto que as rubricas de despesas com Instrução obtidas durante esta pesquisa não fazem distinção dos destinos dos pagamentos feitos ${ }^{15}$.

Mas algumas outras considerações devem ser feitas acerca das escolas particulares na Província. Segundo Anísio Brito (apud NUNES, 1975), paralelo à experiência de Padre Marcos, existia um ensino oficial que se encontrava paralisado, com escolas insuficientes e carentes de professores e sem despertar o menor interesse dos poderes públicos.

Pode-se destacar ainda a experiência de Padre Francisco Domingos de Freitas e Silva que, em sua propriedade, na atual cidade de Piripiri, fundou uma escola primária e um curso de Latim. Além destes dois padres, outros sacerdotes desenvolveram trabalhos bem-sucedidos, mas sem a mesma amplitude.

A experiência de Padre Marcos estimulou o surgimento de outras escolas mantidas por iniciativa privada, tanto de clérigos quanto de proprietários rurais interessados em oferecer as primeiras letras aos filhos. Assim, surgiram vários professores ambulantes ou mestres-escolas que ministraram aulas nas casas dos proprietários rurais ou em locais adaptados, sendo estas escolas predominantemente rurais (BRITO, 1996).

Nunes (1975) contabilizou que, no ano de 1844, a Província do Piauí contava com, pelo menos, 28 escolas particulares:

Encontramos em papéis de 1844 arquivados na Casa Anísio Brito o registro destas escolas localizadas mais na zona rural que nas sedes municipais. Em Valença, por exemplo, havia 9 escolas particulares, em Barras 7, Piracuruca 3, em Príncipe Imperial 2, uma na sede e outra em Pelo Sinal, Parnaguá com 7 distribuídas pelos povoados assim: 4 em Paraim, uma em Gilbués, uma em Curimatá e outra, certamente na sede municipal. Provavelmente tinham escolas particulares em todos os municípios (p. 48).

Para Costa Filho (2006), as formas alternativas de ensino formal eram uma constante no Piauí do século XIX que, paralelamente ao ensino oficial, desenvolveram-se experiências capazes de atender aos interesses dos diferentes grupos sociais. Exemplo disso é o sistema dos mestres ambulantes que se deslocavam pelas cidades, vilas e povoados, ensinando a ler, escrever e contar, além de outras práticas cotidianas necessárias à sobrevivência individual e coletiva.

De maneira geral, a criação e existência do Liceu piauiense exemplificam como se encontrava a Instrução Pública no Piauí da primeira metade do século XIX, já iniciando sua existência com problemas comuns à condição educacional da época, como a falta de recursos para a instalação do estabelecimento e carência crônica de professores, contando, em 1849, com 30 alunos matriculados nas Aulas de Latim, dos quais 17 estavam também inscritos nas aulas de Francês, quatro em Filosofia, seis em Geometria (NUNES, 1975). A matrícula simultânea em mais de uma Cadeira, representa concessão do artigo 10, da lei n. 198, ao permitir que "[...] estas Cadeiras [poderiam] ser acumuladas" (PIAUÍ. APEPI. 4 out. 1845).

Às vésperas da transferência da capital do Piauí, de Oeiras para Teresina, uma fala do Presidente José Antonio Saraiva é precisa ao que se deseja descrever neste estudo sobre a Instrução Pública no Piauí no recorte estudado. Em discurso presente em relatório datado de 1851, Saraiva dá conta de como se encontrava a Instrução Pública Secundária na Província:

\footnotetext{
${ }^{15}$ Cf. Silva, 2007, p. 142, em estudo sobre o Pernambuco, “[...] a prestação de contas do Subsídio Literário era bastante rigorosa no que diz respeito à declaração da arrecadação, mas não dos gastos”. Guardadas as devidas distâncias, podese afirmar que o mesmo aconteceu no Piauí.
} 
nem uma só aula (exceção feita da língua latina e francesa) contava mais de 3 discípulos que iam ouvir as lições, quando bem lhes parecia. Pode-se dizer que o Liceu existia apenas na legislação, e que somente se sabia da existência, quando seus empregados iam receber os vencimentos, que percebiam (PIAUÍ. APEPI. 3 jul. 1851).

Alencastre (2005) corrobora com esta ideia de fragilidade, ao afirmar que o Liceu, “[...] estabelecimento literário, de que tão belos frutos se esperavam, nenhum bem tem trazido à Província, também porque aqueles que a têm governado, depois da sua criação, nunca lhe deram a importância merecida, deixando-a sempre entregue à sua desorganização" (p. 101). Mais uma vez, inscreve-se o descaso com a Instrução Pública à forma como se tratava as dimensões administrativas no cenário local.

Note-se, assim, que se a criação do Liceu representou passo importante ao desenvolvimento do ensino na Província, este ainda se encontrava bastante limitado, frente às dificuldades enfrentadas pela Instrução Pública e pelo próprio quadro político que se apresentava.

Objetivando dar melhores condições de funcionamento ao Liceu, Saraiva aluga uma casa ${ }^{16}$ para suas atividades, mas transferida a Capital de Oeiras para Teresina, em 1852, as aulas desta escola retornaram às casas dos professores. Logo em seguida, esse estabelecimento de ensino também foi transferido e "[...] continuava sua débil vida em Teresina" (NUNES, 1974, p. 54), chegando a ser extinto em 1861. Assim, nos primeiros anos da nova capital, diversas escolas particulares passaram a fazer parte do cotidiano educacional de Teresina que, conforme Chaves (1998), “[...] quase que só os meninos da classe média iam às aulas da Província. Os meninos ricos estudavam de preferência nas escolas particulares, onde o aproveitamento era mais rápido e sensível" (p. 33).

Em referência ao fechamento do Liceu e às "mutiladas" quatro Cadeiras de ensino secundário existentes na Província, o então Presidente, Franklin Américo de Menezes Dória, em 1864, atribuía tal situação à prematuridade da instituição do ensino secundário no Piauí (PIAUÍ. APEPI. 1 jul. 1864).

Verifica-se, então, que com a transferência das responsabilidades sobre a Instrução Pública da Coroa para as províncias, em 1834, houve um incremento no número de "Aulas Públicas" criadas no Piauí. No entanto, estas ficaram em número reduzido às necessidades de distribuição além de continuar a enfrentar problemas com o provimento de professores.

\section{CONSIDERAÇÕES FINAIS}

Embora os documentos oficiais precisem ser investigados e tratados com parcimônia pelo pesquisador, eles contribuem bastante para que o historiador compreenda seu objeto de estudo, pois, "[...] descrever o que se vê, ainda vá, o difícil é ver o que é preciso descrever" (FEBVRE, 1985, p. 24). Assim, sem perder de vista os ensinamentos de Lucien Febvre, entende-se que, ao se olhar esta breve, mas necessária, exposição de como veio se constituindo a Instrução Pública no Piauí, percebe-se que, entre outros fatores, a falta de recursos, o despreparo e o descontentamento dos professores com suas remunerações, marcaram o trajeto educacional piauiense, durante a

\footnotetext{
${ }^{16} \mathrm{O}$ funcionamento de Cadeiras Isoladas em casas alugadas pela administração pública representou fenômeno também presente no Piauí, sobretudo a partir da segunda metade do século XIX. Grosso modo, os prédios escolares somente passaram a pertencer aos bens do patrimônio público, com a substuição do modelo das Cadeiras Isoladas pelo modelo dos Grupos Escolares.
} 
Regência e primeiros anos do Segundo Império, no qual se verifica também a considerável distância entre a estrutura legal e a estrutura real do ensino.

No entanto, não pode ser esquecido que a dispersão da população e sua concentração na zona rural, bem como as dificuldades de acesso às escolas - seja pela distância física, seja pela distância de objetivos - atuaram como fatores a serem considerados para o esvaziamento do ensino público, contribuindo decisivamente para os resultados obtidos no período em estudo.

Ainda deve ser levado em conta que a legislação educacional contribuiu para o esvaziamento das Aulas públicas, ao dispensar a matrícula e a frequência dos alunos em uma escola oficial e possibilitar o acesso de um nível a outro do ensino sem a necessidade da apresentação de diplomas ou certificados de conclusão do nível antecedente, limitando a ação das escolas públicas.

Verifica-se assim, que a Instrução Pública no Piauí, durante a Regência e primeiros anos do Segundo Império, continuava em segundo plano e enfrentando graves problemas, uma vez que "[...] o elemento de realidade estava posto pela situação financeira da Província e a não prioridade da educação (...). Este fato é responsável pelo lento espalhar-se da rede pública escolar e por suas idas e vindas, em termos de criação e fechamento de escolas" (LOPES, 1996, p. 54-5). Todavia, além da inexistência de recursos financeiros e carência de professores qualificados - situação esta que perdurou e pouco se modificou ao longo da história piauiense - o que mais prejudicou a estruturação da Instrução Pública no Piauí foi a falta de vontade política de governantes em criar um sistema de ensino público conjugado com o processo de desenvolvimento da região.

\section{REFERÊNCIAS}

ALENCASTRE, José Martins Pereira de. Memória cronológica, histórica e corográfica da província do Piani. Teresina: SEDUC, 2005.

ALMEIDA, José Ricardo Pires de. Instrução pública no Brasil (1500-1889). Trad. Antonio Chizzotti. 2 ed. rev. São Paulo: EDUC, 2000.

BASTOS, Maria Helena Câmara. O ensino monitorial/mútuo no Brasil (1827-1854). In: STEPHANOU, Maria; BASTOS, Maria Helena Câmara (Orgs.). História e memória da educação no Brasil. Petrópolis, RJ: Vozes, v. I, 2005.

BONAVIDES, Paulo; AMARAL, Roberto. Textos políticos da bistória do Brasil. 3. ed. Brasília: Senado Federal, Conselho Editorial, 2002.

CARDOSO, Tereza Fachada Levy. As aulas Régias no Brasil. In: STEPHANOU, Maria; BASTOS, Maria Helena Câmara (Orgs.). História e memória da educação no Brasil. Petrópolis, RJ: Vozes, v. I, 2004.

CHAVES, Joaquim Raimundo Ferreira. Obra completa. Prefácio de Teresinha Queiroz - Teresina: Fundação Cultural Mons. Chaves, 1998.

COSTA FILHO, Alcebíades. A escola do sertão: ensino e sociedade no Piauí, 1850-1889. Teresina: Fundação Cultural Mons. Chaves, 2006.

COSTA, Francisco Augusto Pereira da. Cronologia histórica do estado do Piauí. Rio de Janeiro: Artenova, v. I e II, 1974.

FÁVERO, Osmar (Org.). A educação nas Constituintes brasileiras: 1823-1988. 2. ed. rev e amp. Campinas, SP: Autores Associados, 2001.

FEBVRE, Lucian. Combates pela história. v. I. Lisboa: Editorial Presença, 1985. 
DOI: $10.12957 /$ teias. $\%$ Y.50069

FERRO, Maria do Amparo Borges. Educação e sociedade no Piauí republicano. Teresina: Fundação Cultural Mons. Chaves, 1996.

GONDRA, José Gonçalves; SCHUELER, Alessandra. Educação poder e sociedade no Império brasileiro. São Paulo: Cortez, 2008.

LOPES, Antonio de Pádua Carvalho. Beneméritas da instrução: a feminização do magistério primário piauiense. Dissertação de Mestrado. Fortaleza- CE, 1996.

NEVES, Abdias. O Piaui na confederação do Equador. Teresina: Ed. EDUFPI, 1997.

NUNES, Odilon. Pesquisas para a história do Piaui. Rio de Janeiro: Artenova, v. IV, 1975.

PINHEIRO, Antonio Carlo Ferreira. Da era das cadeiras isoladas à era dos grupos escolares na Paraíba. Campinas, SP: Autores Associados, São Paulo: Universidade São Francisco, 2002.

SILVA, Adriana Maria Paulo da. Processos de construção das práticas de escolarização em Pernambuco, em fins do século XVIII e primeira metade do século XIX. Recife: Editora Universitária da UFPE, 2007.

SOUSA NETO, M. Padre Marcos e sua Boa Esperança: instrução pública e política no Piauí (18201850). Gênero \& História (UFPE). v. 3, 2005, p. 79 - 105. Disponível em https://periodicos.ufpe.br/revistas/cadernosdehistoriaufpe/article/view/110128

STEPHANOU, Maria; BASTOS, Maria Helena Câmara (Orgs.). História e memória da educaşão no Brasil. Petrópolis, RJ: Vozes, v. I, 2005.

\section{DOCUMENTAÇÃO PRIMÁRIA}

BRASIL. Lei de 15 de outubro de 1827. Manda criar escolas de primeiras letras em todas as cidades, vilas e lugares mais populosos do Império. Art. $4^{\circ}$. Coleção de Leis do Império. 1827. I Parte. Rio de Janeiro: Typographia Nacional, 1878a.

BRASIL. Ato Adicional de Interpretação à Constituição de 1824. Lei n. 16, de 12 de agosto de 1834. Coleção de Leis do Império. 1834. Rio de Janeiro: Typographia Nacional, 1878b.

PIAUÍ. AHU. Aviso do [secretário de estado da Marinha e Ultramar, visconde de Anadia [João Rodrigues de Sá e Melo], ao [conselheiro do Conselho Ultramarino], barão de Moçâmedes, [Manuel de Almeida e Vasconcelos Soveral de Carvalho Maia Soares de Albergaria], ordenando que o Conselho Ultramarino dê seu parecer sobre o requerimento de Matias de Lima Taveira, em que pede para ser nomeado professor de gramática latina para a cidade de Oeiras no Piani. Cx. 20, doc. 25, D. 1353, Lisboa, 1 de julho de 1803.

PIAUÍ. AHU. Ofício da Junta Governativa do Piauí, ao secretário do estado da Marinha e Ultramar, Inácio da Costa Quintela], sobre a situação lastimosa da instrução pública na provincia do Piaui, relatando a forma como foram criadas cadeiras de primeiras letras e de gramática latina e os baixos salários pagos aos seus mestres. Cx. 24, doc. 28, D. 1619, Oeiras, 25 de fevereiro de 1822.

PIAUÍ. AHU. Provisão do Junta Governativa do Piauí, sobre o provimento de João Lobo Fróis, como professor da cadeira de gramática latina, criada na cidade de Oeiras do Piaui por ordem régia. Cx. 24, doc. 2, D. 1612, Oeiras 15 de Janeiro de 1822.

PIAUÍ. AHU. Provisão do príncipe regente [D. João], criando na cidade de Oeiras do Piauí, uma cadeira de gramática latina. Cx. 23, doc. 46, D. 1596, Rio de Janeiro, 3 Agosto de 1818.

PIAUÍ. APEPI. Ata da $7^{a}$ Sessão do Conselho de Governo da Província do Piani, de 30 de dezembro de 1826. Sala do Poder Executivo. Província do Piauhy - Actas, 1825-1831.

PIAUÍ. APEPI. Ata da Sessão Extraordinária do Conselho de Governo da Província do Pianí, de 28 de abril de 1828. Sala do Poder Executivo. Província do Piauhy - Actas, 1825-1831. 
DOI: $10.12957 /$ teias. $\%$ Y.50069

PIAUÍ. APEPI. Decreto de 06 de setembro de 1843. Sala do Poder Executivo. Livro de Registro de Leis e Resoluções, 1843-1848.

PIAUÍ. APEPI. Decreto de 20 de agosto de 1836. Sala do Poder Executivo. Livro de Registro de Leis e Resoluções, 1843-1848.

PIAUÍ. APEPI. Fala com que o Excelentíssimo Senhor Presidente desta Provincia abriu a sessão ordinária da Assembleia Provincial de 1840. Sala do Poder Legislativo. Registro de Correspondência da Assembleia Legislativa, com o Governo da Província, 1835-1843.

PIAUÍ. APEPI. Fala do Barão da Parnaíba [Manoel de Sousa Martins] à Assembleia [Legislativa Provincial], no ato de sua instalação, em 04 de maio de 1835. Sala do Poder Legislativo. Registro de Correspondência da Assembleia Legislativa, com o Governo da Província, 1835-1843.

PIAUÍ. APEPI. Fala do Excelentíssimo Senhor Presidente da Provincia na instalação da Assembleia Legislativa Provincial, em 10 de agosto de 1838. Sala do Poder Legislativo. Registro de Correspondência da Assembleia Legislativa, com o Governo da Província, 1835-1843.

PIAUÍ. APEPI. Fala que o Excelentíssimo Senhor Presidente desta Provincia abriu a sessão ordinária Assembleia Provincial em 13 de julho de 1837. Sala do Poder Legislativo. Registro de Correspondência da Assembleia Legislativa, com o Governo da Província, 1835-1843.

PIAUÍ. APEPI. Fala que reciton o Excelentíssimo Senhor Visconde da Parnaíba, Presidente desta Provincia do Piaui, na ocasião da abertura da Assembleia Provincial em 7 de julho de 1843. Sala do Poder Legislativo. Registro de Correspondência da Assembleia Legislativa, com o Governo da Província, 1835-1843. PIAUÍ. APEPI. Fala, que reciton o Excelentíssimo Senhor Barão da Parnaíba, Presidente da Provincia do Pianí, na ocasião da abertura da Assembleia Legislativa Provincial, no $9^{\circ}$ de julho do corrente ano de 1838. Sala do Poder Legislativo. Registro de Correspondência da Assembleia Legislativa, com o Governo da Província, 1835-1843.

PIAUÍ. APEPI. Fala, que reciton o Excelentíssimo Senhor Visconde da Parnaíba, Presidente desta Província do Piani, na ocasião da abertura da Assembleia Legislativa Provincial, em 4 de outubro de 1842. Sala do Poder Legislativo. Registro de Correspondência da Assembleia Legislativa, com o Governo da Província, 1835-1843.

PIAUÍ. APEPI. Lei n. 198, de 4 de outubro de 1845. Institui o cargo de Diretor de Instrução Pública, cria na cidade de Oeiras um Liceu e dá outras providências. Art. $8^{\circ}$. Sala do Poder Excecutivo. Livro de Registro de Leis e Resoluções, 1843-1848.

PIAUÍ. APEPI. Lei n. 31, de 17 de setembro de 1938. Coleção de Leis da Província do Piauí. Oeiras: Tipographia Provincial, 1838.

PIAUÍ. APEPI. Lei n. 86, de 20 de setembro de 1838. Coleção de Leis da Província do Piauí. Oeiras: Tipographia Provincial, 1838.

PIAUÍ. APEPI. Lei Provincial n. 75. Obriga os professores da Província a assistir pessoalmente as lições diárias dos alunos. Sala do Poder Legislativo. Série: Leis e Resoluções. Folha: 01 avulsa. 20 de setembro de 1837.

PIAUÍ. APEPI. Livro de posses da capitania. Sala do Poder Executivo, 1814-1859.

PIAUÍ. APEPI. Ofício da Assembleia Legislativa da Província do Piaui ao Governo da Província, deliberando sobre o número de alunos nas aulas de Francês na cidade de Oeiras, em 12 de setembro de 1937. Sala do Poder Legislativo. Registro de Correspondência da Assembleia Legislativa, com o Governo da Província, 1835-1843. 
PIAUÍ. APEPI. Ofício da Câmara de Jaicós à Assembleia Legislativa Provincial, solicitando gratificação especial ao fiscal da Vila. Sala do Poder Legislativo. Correspondências da Assembleia Legislativa Provincial,

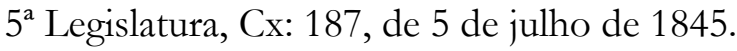

PIAUÍ. APEPI. Ofício encaminhado pela Câmara Municipal de Jaicós, à Assembleia Legislativa Provincial, informando a substituição do Agente dos Correios daquela Vila. Sala do Poder Legislativo. Legislativo Municipal, Jaicós, cx: 93, 5 de outubro de 1835.

PIAUÍ. APEPI. Relatório do Presidente da Província, Dr. Franklin Américo de Menezes Dória, a Assembleia legislativa provincial, em $1^{\circ}$ de julho. Teresina: Typ. B. de Mattos. 1864.

PIAUÍ. APEPI. Relatório do Presidente da Provincia, Dr. José Antonio Saraiva, à Assembleia Legislativa Provincial, em 3 de julho de 1851. Oeiras: Typ. Saquarema, 1851.

PIAUÍ. APEPI. Relatório do Presidente da Provincia, Dr. Zacarias de Góes e Vasconcelos, a Assembleia legislativa provincial, em 11 de julho. Oeiras: Typ. Provincial. 1846.

PIAUÍ. APEPI. Resposta à fala do excelentíssimo Senhor Presidente da Provincia, na instalação da Assembleia Legislativa Provincial, em 15 de maio de 1835. Sala do Poder Legislativo. Registro de Correspondência da Assembleia Legislativa, com o Governo da Província, 1835-1843.

PIAUÍ. APEPI. Resposta à fala do Excelentíssimo Senhor Presidente da Provincia na instalação da Assembleia Legislativa Provincial, em 10 de agosto de 1838. Sala do Poder Legislativo. Registro de Correspondência da Assembleia Legislativa, com o Governo da Província, 1835-1843.

PIAUÍ. APEPI. Termo de juramento e posse de Dona Maria Ferreira do Nascimento, professora de primeiras letras para meninas pelo método múltiplo na Vila de Campo Maior, em 13 de maio de 1837. Sala do Poder Executivo. Livro de posses da capitania, 1814-1859.

Submetido em abril de 2020

Aprovado em novembro de 2020

\section{Informações do autor}

Marcelo de Sousa Neto

Universidade Estadual do Piauí/Universidade Federal do Piauí

E-mail:marcelo@ccm.uespi.br

ORCID: https://orcid.org/0000-0002-2748-2316

Link Lattes: http://lattes.cnpq.br/2608763010341838 